\title{
Digital construction for analysis: the Scalambri defensive system in Sicily
} Anna Frascari $^{\mathrm{a}}$, Angela Mancuso ${ }^{\mathrm{a}}$, Andrea Pasquali ${ }^{\mathrm{a}}$

a Dipartimento di Architettura, Florence University, Italy, annafrascari@hotmail.it, mancusoangela@hotmail.com, pasqualiandrea@yahoo.it.

\begin{abstract}
This research is focused around Italian defensive system on the southern coast of Sicily, in the territory of Ragusa. Object of this study is the system consisting in three coastal watchtowers, located in three hamlets in Santa Croce Camerina, a small town near Ragusa. These works of military engineering are nominated as Torre Vigliena in Punta Braccetto, Torre di Mezzo (or Torre di Pietro) in the homonym hamlet and Torre Scalambri in Punta Secca.

Despite their poor state of preservation, these towers have always been an eye catcher for their territory. Today, observing this defensive system, one can note a variable state of decay: their original geometric characteristics and morphological shapes are not clearly legible.

This work consist in a first historical investigation, useful for the temporal location and for the comprehension of the roles of these towers.

Following, the study develops with the investigation of the environmental characteristics, to better understand the tower orientations and their observation devices.

The comparison between the three towers and with other examples from Sicily, numerous not only on the coastal area, will create a volumetric hypothesis; this construction, positioned in the virtual world of Google Earth, will complete the analysis providing valid observation points for the evaluation of their placement on the coast.

The study presented will be completed with an overview of the inner relations of the defensive tower system, regarding their volumes, geometry, materials and functions: this to better understand design strategy of settlement and to create a model comparable with other similar defensive configurations.
\end{abstract}

Keywords: observation towers, Sicily, defense system, Google Earth.

\section{Introduction}

Over the centuries the Mediterranean Sea has been in a privileged position between nautical activities, international trades of precious goods, migration of people and slave trades. The tracks of the Mediterranean piracy are dated back to the II millennium BC. The business of piracy has evolved over the centuries, and it has grown exponentially since the XV century when the rivalry between Aragonese, Spanish, French and Turks, have become more acute because of the fragmentation and the resulting weakness of the
Italian States. The activities of the pirates concern both about assaulting mercantile ships and attacking coastal cities to enslave their citizens. The Sicily island, part of the Spanish Reign, was particularly exposed both for its geographically position and for the on-going conflict between Spanish and Turks, Christianity and Islamism. Moreover it could be used as a medium point, to rest in during other incursions. 


\section{The origin of the Sicilian Defensive System}

In Sicily there were some pre-existing towers dated back to the Byzantine and the Normans, but these ancient buildings did not constitute a strong and coherent defense. The first and the more ancient attempt to strengthen this system , was made by the King Martino I il Giovane (1374-1409). For his project, 12 of all the existing towers had to be restored and 23 new towers had to be erected. Two centuries later, during the reign of Carlo V of Habsburg (15001558), Juan de Vega (1507-1558) was at the vice and structured the re-projecting of the tower system to respond to a growing number of piracy incursion. The number of the towers built by Vega between 1549-1553 is not certain, but we know that his towers were not built as isolated elements but were a well structured observation and communication system, working by the tower fires, called fani1. However, even after the improvement made by Vega, the final number was still too low to well protect the island. After about twenty years, the vice Marcantonio Colonna (1535-1584), decided to continue improving the tower system. He hired the engineer Tiburzio Spannocchi (1543 - 1606) to first of all, study the state of the system and give a relation about it. In 1578 he wrote the report called "Descriptiòn de las marinas de todo el reino de Sicilia". It talks about 62 existing towers, to be restored and consider the building of 123 new towers, that together with the 24 castles of the major coastal cities, could create an efficient communication system. The Sicilian parliament appropriate 10.000 scudi2 to build the tower system designed by Spannocchi, but nowadays, we have got any certainty about how many towers had been built according to the design of Spannocchi and how many others are part of a next project. As a matter of fact, in July 1583, the Deputazione del Regno3 hired the architect Camillo Camilliani (XVI century 1603) to follow Giovan Battista Fresco (The Captain of the Deputazione) in his usual examination tour of the towers all around Sicily, aimed to report their state of conservation. The primary role of Camilliani in this journey, was to draw down the actual morphology of the coast, evaluating the places marked by Spannocchi as locations for the new towers not yet been built. In this way Camilliani had the opportunity to document whether the sites chosen by Spannocchi were appropriate or not, and eventually to choose different locations or remove the towers deemed unnecessary. In this campaign G. B. Fresco wrote down "Cosmografia del litorale di Sicilia con la descrizione delle città, terre, castelli torri marittime" (1583), a detailed description both of the practical methods to restore the existing towers and of the typology characterics of the new towers to be erected. All these notions were the result of a technical culture of military building tradition, already established at his time.

Together with the work of Fresco, Camilliani wrote down a relation called "Descrittione delle marine di tutto il regno di Sicilia con le guardie necessarie da cavallo e da piedi che vi si tengono". This works was divided into three volumes containing an historical and landscape background of Sicily; his design for the new towers and the last volume, better known as "Il libro delle torri" contains the drawings of them. In his descriptions, Camilliani takes in consideration also the eventual necessity of a restoration for the existing towers and he designed also the position of armaments on every single tower. The position of every tower was established to let all the adjacent towers to be in visual contact; never forgetting the economy of the project. Despite a careful planning, the number of the buildings was very high due to the extension of the coast and to its rugged morphology. The project of Camilliani, diverged from the Spannocchi's, confirming only 90 towers of 125, moving 15 structures, eliminating 20 of them, and replaced them with other private tower already existing and adding 19 new elements. Examining the effective position of them, one can notice that Camilliani mostly followed the locations designated by the project of Spannocchi and even if the towers was funded by the parliament, and the design worked well, not all of the projected towers has been realized, but the communication system was anyway operating in some zones of the island. 
All these towers were built before 1640 and they will keep their original function until the beginning of XIX century. We can resume that the master plan structuring all this tower system has been realized by the head of the government (thanks to Spannocchi), while to the Deputazione was committed the technical design and the management of the towers (with the work of Fresco and Camilliani).

\section{The Scalambri defensive system in Santa Croce Camerina (RG)}

Present day the defensive system is part of the province of Ragusa, in the Mediterranean area. Historically this province belonged to the bigger area of Val di Noto, one of the three different administrative regions created during the Muslim ruled period. The geographical areas of the three regions were: the western third for the Val di Mazara, the southeastern third for the Val di Noto, and the northeastern third for the Val Demone. Sicily maintained its Arabic division in three principal valli6 until the beginning of XIX century. Comprehending the territory of the actual provinces of Catania, Siracusa and Ragusa, in this area comprehends 29 towers.

\subsection{Torre Vigliena}

Torre Vigliena is located at the end of "braccio della Colombara" that, nowadays, is named Punta Braccetto. The tower is very close to the seaside in a thin level land that tend to the sea. From this privileged position the tower can control both the adjacent gulfs: towards the South it looks to the towers of Pietro and Scalambri and to the North-side it looks toward a tower that has never been built (Torre de Blanco Grande, projected by Camilliani) on the Gulf of Gela. The construction started in 1595 under the jurisdiction of the Marquis of Santa Croce and ended in 1607 under the viceroy of the Marquis of Villena (that gave it his name). At the end of the XVII century is indicated as a guardian tower by Filippo Geraci in his Portolano; he specifies that, during the summertime, this part of the coast repaired the shoreline, both if the winds were from the West or from Scirocco. Analyzing a transcribed document wrote by the Deputazione in 1717, this tower is defined as a Torre di Deputazione and is under the jurisdiction of the marquis of Santa Croce.

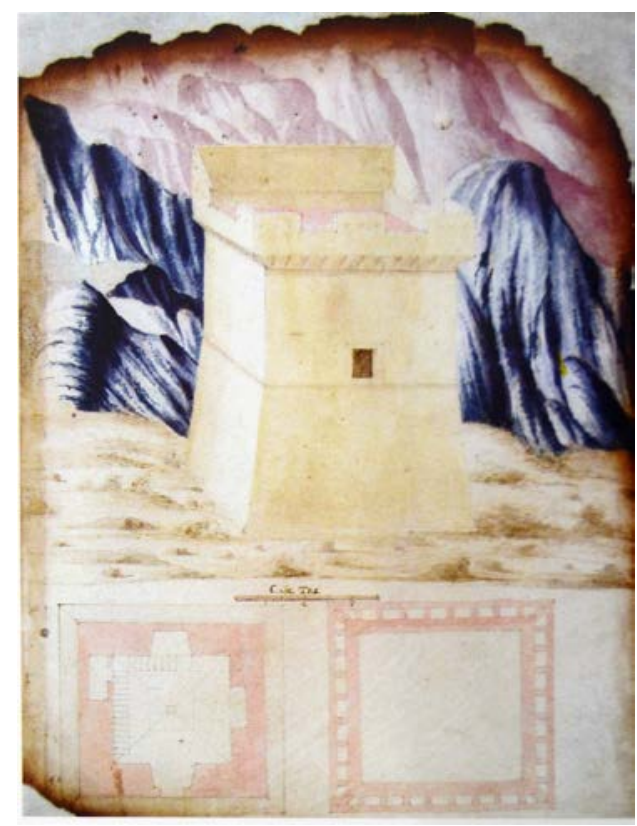

Fig. 1- Torre Vigliena (Maurici, 2008)

The document also says that the building was well armed with two iron cannon on wheels, a musket and a bronze mascolo5 for alerts and was guarded by three men (one corporal, one artillerymen, and a soldier). The military use of the tower will end a few years later: in 1867 was included in the list of military works to be dismissed. Later the tower was reused during the II World War; for this purpose the interior of the building was filled with soil to create a plan base for an artillery station. Today the tower has a square plan with sides of about $11.30 \mathrm{mt}$ and a maximum height of $5.50 \mathrm{mt}$. The visible masonry is the original interior of the thick double layered wall that have been deprived of the outer covering of stone ashlars. Comparing the remains with the project drawings of Camilliani we can still identify a typical project with a truncated pyramidal base level and a jutting out crowning element. Near the ruins of the tower are still presents the remains of another rectangular based building probably 
used as barracks during the II World War; to safely connect this two constructions was also created a tight $(0,65 \mathrm{mt})$ path protect by a wall between them.

\subsection{Torre di Mezzo (or Torre di Pietro)}

This tower is also known as Torre di Pietro or Torre di Santa Croce. It is located at a middle point between Punta Secca and Punta Braccetto on a coast-head not so higher than the sea level. In 1578 the engineer Spannocchi introduce the necessity of a tower at La Secca, that comprehend the coastline between Capo Scalambri until Punta di Mezzo. The definitive location of the building was proposed by Camilliani, in 1584, following the project of Spannocchi, with the aim to prevent the landing of the pirates, and the opportunity for them to make supplies of drinking water from the ancient Santa Croce River4, which flowed into the adjacent gulf. For this reason he introduced the necessity to arm the tower, ensuring that it had not only a signaling function. The tower of the Deputazione had been built at the beginning of 1600 and it was under the jurisdiction of Santa Croce. Its presence is documented at the end of the XVII century on the Portolano of Filippo Geraci. Pippo Lo Cascio, analyzing a document made by the Deputazione in 1717, collocates the tower under the jurisdiction of the marquis of Santa Croce; it was guarded by four men (one corporal, one artillerymen, and two soldiers) and was armed with two bronze cannons, six muskets, one mascolo5 and one bell. In 1867 the tower was in a list of military works to be dismissed (Russo 1994, Vol. II). Nowadays we can see only the ruins of the original tower as it had been destroyed during the II World War. This building, as showed in the watercolor painting of Camilliani, is a typical truncated pyramid tower with a squared base $(10,50 \times 10,50 \mathrm{mt})$, oriented with its corners towards the cardinal points. At the first floor there was a door facing the land. Its cornice is constituted by jutting out battlements on stone corbels. The walls of the towers has got a thickness of $2 \mathrm{mt}$ and they were made with stone, mortar and then refined with plasterwork. The corners are made by big ashlars of about
1,60 mt wide; this kind of corner masonry proceed for the entire height of the tower. Between the scarp wall and the first floor there was a roundish cornice $0,30 \mathrm{mt}$ wide, still visible on the North-West side and partially on NorthEast side. From the remains one can see that the ground floor was divided into two equals rooms by a wall of a large thickness. Actually, despite the growth of urban settlements, from the site is still possible to see the two adjacent tower Scalambri and Vigliena.

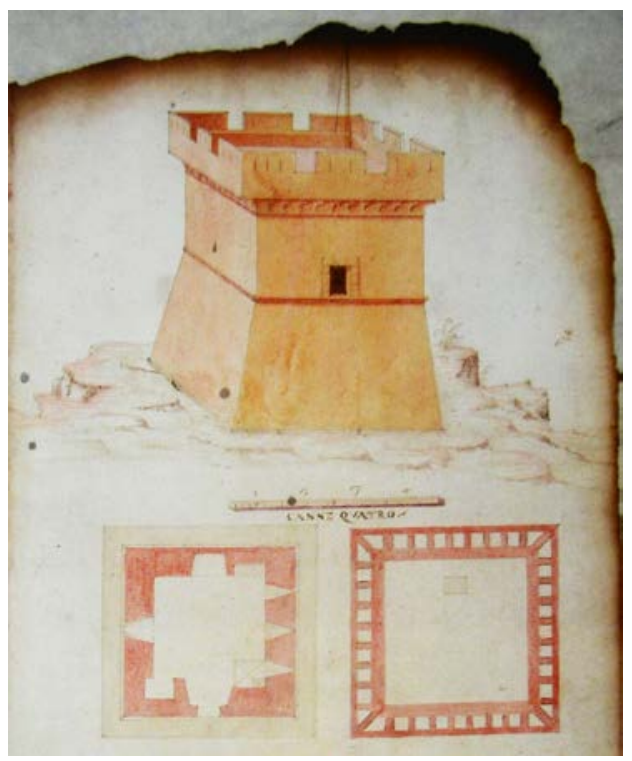

Fig. 2- Torre di Mezzo (Maurici, 2008)

\subsection{Torre Scalambri}

This tower is located in the homonym hamlet of Punta Secca, close to the shoreline. On the North side it had to be connected with the Anecheghef Tower, never built; on the North-West side with the Torre di Mezzo and on the South-East side with the Torre Mazzarelli. Camilliani to convince the Deputazione in building this towers, added also the motivation of maintain safe the population of the village. In 1596-1597 Giovanni Cosimo Bellomo decided to build this important tower himself, with the compliments of the Deputazione, that will exonerated him of all the other expenses. Its presence is documented at the end of the XVII century on the Portolano of Filippo Geraci. 


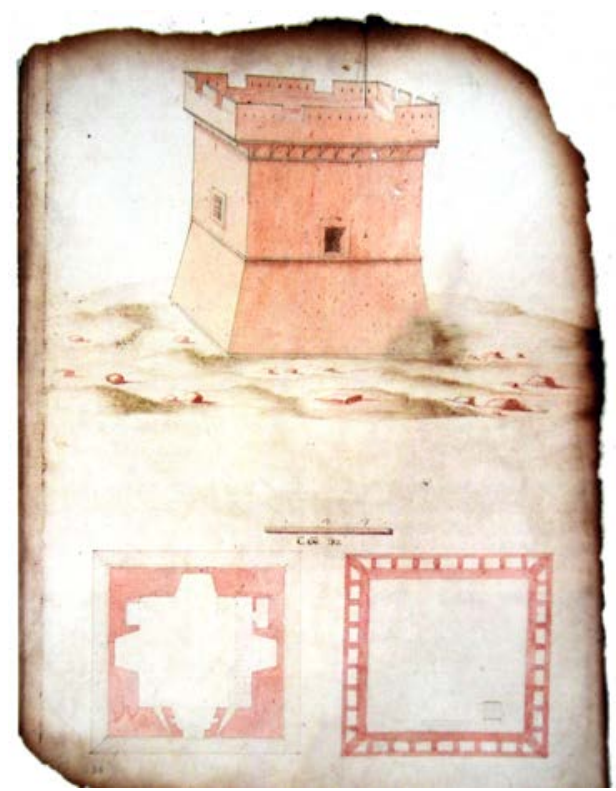

Fig. 3- Torre Scalambri (Maurici, 2008)

The document analyzed by Lo Cascio, collocates the tower under the jurisdiction of the marquis of Santa Croce; it was guarded by four men (one corporal, one artillerymen, and two soldiers) and was armed with ten muskets, one bronze cannon, three mascolo5, four halberd and one bell. The construction followed the project of Camilliani, that we can observe on his watercolor painting. It was a typical truncated pyramid tower but with a rectangular base $(8,50 \times 9,20 \mathrm{mt})$, with two levels over the scarped ground floor that contained the water tank. At the first floor there was the entrance door, guarded by two embrasure and two windows; in the inside, there were two niches for storage, obtained in the wall depth; at the second level there was the terrace, with a corner of jutting out battlements on stone corbels, that you could access by stairs inside the wall depth. The corners, as we can observe in Torre di Mezzo, are made by big ashlars of about 1,60 mt wide, laying down for the entire height of the tower. Since about 1960, the building was started to use with residential purposes, and for this reasons it has been restored without any historical continuity. As a matter of fact until 2013 the exterior of this tower was completely distorted due to a bad cement plaster, and to the construction, on three of the four sides of the tower, of three order of balconies in contemporary walling, some on pre-existing tuff corbels and some others on reinforced concrete bases. Moreover this ancient tower appears linked to another house, with a contemporary bridge in reinforced concrete. At the end of 2013, the owners started the restoration works, and today, even if they are not complete, we can see the tower like it was in the past, with the only exception of the scarp wall basement, embedded in the repaving works.

\section{Digital simulation of Scalambri system}

After the historical research of the three towers, the study develops with the investigation of the environment to comprehend the relations between the towers positions and orientations and their observation devices. The final aim is to create, with the help of digital technologies, some volumetric hypothesis that, when positioned in Google Earth, provides valid observation points for the evaluation of their placement along the coast.

\subsection{Workflow about the Scalambri Re-Born}

This phase-study has been developed through different 3D software, simulating the layout of the territory as it was in the XVI century, thanks to the reconstruction of the towers founded on the documentation of the period. This works could be virtually divided into four phases, linked one to another and always appropriate because verified with the sources available. The planning phase has focused the targets of the research, the territorial zones to be analyzed, the methodologies to actuate the study with and the identification of the technologies useful to the study and the conclusions. The first part of the works comprehends the visit to the sites, with observations, measurements and photographic shooting, calibrated on subsequent stages; moreover it comprehends the visit of the local archives to search peculiar documents available only in the administrative territory near to the area of interest. This stage is very useful also to be more close to the site and to have the possibility to relate to a human dimensions the 
entity of the towers and the notion of the dimensional of the system, finalized to the evaluation of the final digital results. The second phase was the selection of all the material collected, with the aim of dividing the information more useful for the historical knowledge of the towers, from the ones more suitable to the digital rebuilding. The digital phase would have the aim of recover an unitary observation, now definitely lost because of the disappearance of the managing defensive system of the towers on all the territory, and above all, because of the anachronism of the typology of military structures. This third phase of reconstruction begins with the elaboration of the survey data collected, necessary for the digital modeling. This phase, described below, is made up of some additional sub-operational steps that lead to the creation of simplified threedimensional models and of their digital environment through the inclusion on Google Earth. The reconstruction of the models of individual towers was performed trying to ensure the maximum in the scientific process; then through the matching of direct measurements with bibliographic information, one can obtain the proper development of the heights of the walls, now disappeared or invaded by posthumous building works. Some operations of digital photogrammetry, applied to the survey campaign dedicated photo, allowed to obtain a geometric survey of the current configuration, not strictly useful to the operations of simulation but essential to provide a given documentation of the contemporary state of conservation, proper and necessary for the works of cultural significance. This stage was performed in software dedicated to the management of polygon meshes (Maxon Cinema 4D) for the structuring of individual models of the towers. As already mentioned, the most relevant point to be solved was obtaining the correct size of the elevations: while the size of the plans are still totally accessible, and widely cited by all the texts related to the theme, the heights are not observable right now. Then the next step is to proceed through the interpretation of the sources, specifically watercolors paintings of Camilliani, providing the norm applied to the sizing of individual towers defined on each building depending on the morphology of the site. Camilliani proposes the size and position of every single tower, following the analysis of the surroundings, the peculiarities of the site and the strategic importance of the portion of the coast, linking it to the traditional knowledge of the time and the Portolani. With the proportions derived from the measurement of the sides of the plant, we get the guidelines of the project. These will determine wall thickness and proportion and qualification of the elevations.

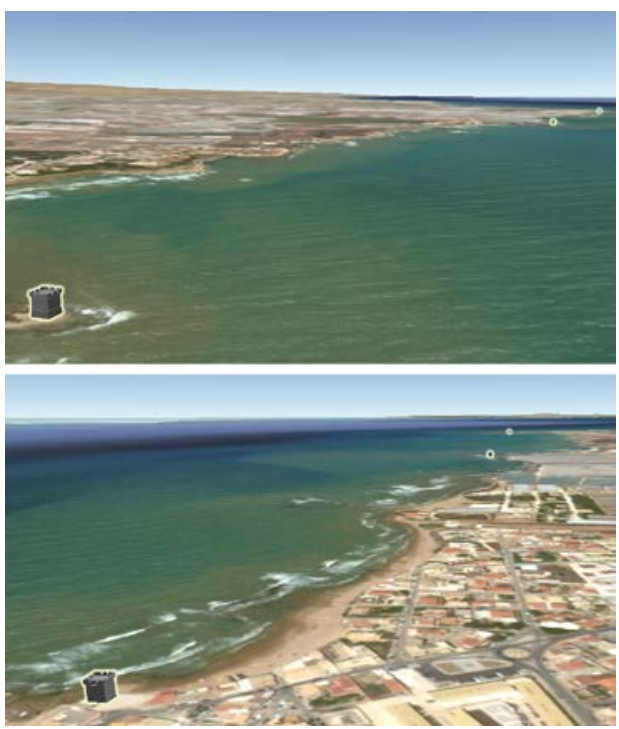

Fig. 4- Google Earth screenshots (Frascari, Mancuso, Pasquali, 2015)

Depending on the measure of the base side the height could be determined finding two possible configurations: one with a facade inscribed in a square shape and one inscribed in a golden rectangular. This concludes the third phasestudy, from which the virtual models are scientifically constructed even if simplified, thus obtaining a correct and consistent basis for personal observations and study. The next phase, obtained consequently to specific features of digital communication between software of different nature (exporting models compatible format Collada.dae) arrives on Google Sketchup, necessary for the transition on Google Earth. In Sketchup have not been applied any editing procedures on models but, following a forced 
workflow, were positioned in portions of land designated, through the procedures of rototranslation of the models (adapting it to the spatial conformation given). So this is the procedure useful to the "jump" into Google Earth. The job done gives back the dimensions of the towers and their actual distance relationships, located on the real territory characterized and defined by geographical survey, on which is based Google Earth. From the results of historical research and combining these to the digital model built, one can get an overall scenario useful for the every kind of final considerations.

\section{Conclusions}

To conclude the studies outlined above and the final synthesis, obtained by the intersection of the bibliographic sources with the digital simulation, it was possible to propose the following conclusions. The coastal defense system of Capo Scalambri is part of a larger system distributed throughout the Sicilian territory and then raised on pre-existences and consolidates. The character of unitary construction of the works is clear and deriving from a single constitutive project, result from careful observations. In the guidelines of the project, summarized as a code created by Camilliani on a model already present in the territory of southern Italy contemporary with him, are indicated both structural constraints and allocation of military resources. From this it can be understood as the issues of territorial defense and the strategic importance of the individual portions of the coast were already established in the knowledge and relevant historical facts. The presence of a code further confirms the necessity of reading as a system the organism of defense resulting from all the towers and also reveals how the optimal operation occurred only with the presence of all the volumes of defense.

This is easily revealed by volumes proportionally similar, both at a large scale and in our case (observation of three components of a complex system): the difference of the heights is minimal, finding a non-hierarchical system in which is not distinguishable a point of vulnerability. The tower are in direct line of sight, and the allocation in each tower of also blank ballistic devices, emphasizes the characteristic of the system of recognition act for observation and prevention. The defensive system studied, can be defined a unique finalized to the reconnaissance; this is supported by the observation of the ancient Portolani, by the observation of the winds and of the prevailing currents, that blowing in a only direction can classify the line of sea relating to the towers until the island of Malta. In this way it manifests the nature of maritime navigation in this area: the mere passage, the transition from coast to coast. Another note in support of this is that the shape of Capo Scalambri is convex, without inlets and reliefs and so without any current protector. The role of the system was not properly active in the war activities. The actual state of conservation should not deceive us: the almost complete disappearance or morphological characters or entire volume is due not to battles of the period, but to the reuse of individual elements considered and used only as isolated towers and exploited for their chances in the modern era. Denaturing these buildings to their means and using them during battles with advanced weaponry, they reacted as a single entity, not taking advantage of the huge potential of the connection between the parts of the territory, which was wonderfully designed in the era of their construction.

\section{Notes}

(1) fani: from greek "phanòs" for torches, guiding lights. There were signals emitted by one place to be visible from a far distance. During the daylight, this signals were made by smoke, and only during the night, they used to light fires.

(2) scudi: a type of coins used in Sicily until the 19th century.

(3) Deputazione del Regno: a governing-body of the Reign of Sicily, born during the XV century and voted by the three department of the Parliament (military, clerical and state property administration). 
(4) "assicurare che il corsale non possa accomodarsi, nè pigliare l'acqua al detto fiume (Fiume S. Croce)", in Camilliani by Di Marzo.

(5) mascolo: big breech-loaded tube filled with gunpowder, in which there was the chamber, to give an advise shot to the population in case of enemy attack. The Petriere mascolo was a breech-loaded swivel gun.
(6) valli: in modern Italian is the lower zone between two hillside. The origin of this name could belong to the Arab wālī, which refers to the government of the areas or to the Norman iqlīm, referring to the territory.

\section{References}

Braudel F. (2002). Civiltà e imperi del mediterraneo nell'età di Filippo II. Einaudi. Torino

Camilliani C. (1877). "Descrizione dell'isola di Sicilia" in Biblioteca Storica e Letteraria di Sicilia by G. Di Marzo. P. Lauriel Ed. Palermo.

Camilliani C. (1979). "Il «Libro delle torri marittime»" in Storia della città by Aldo Casamento. Electa.

Di Matteo S. (1986). Torri di guardia dei litorali della Sicilia. Giada Ed. Palermo.

Lo Cascio P. (2000). Le torri siciliane di deputazione del 1717. Ist. Siciliano di Studi Politici ed Economici Ed. Palermo. pp. 9-30, 104-109, 113-121.

Maurici F., Fresina A., Militello F. (2008). "Storia, architettura, ambiente" in Le torri nei paesaggi costieri siciliani (secoli XIII-XIX). Regione siciliana, Ass. dei beni culturali, ambientali e della pubblica istruzione, Ed. Palermo.

Maurici F., Fresina A., Militello F. (2008). "Torri del Val di Noto e del Val Demone" in Le torri nei paesaggi costieri siciliani (secoli XIII-XIX). Regione siciliana, Ass. dei beni culturali, ambientali e della pubblica istruzione Ed. Palermo. pp. 36-55.

Mazzamuto A., (1986) "Architettura e Stato nella Sicilia del '500" in Atlante di Storia Urbanistica Siciliana, by E. Guidoni. S.F. Flaccovio Ed. Palermo.

Mazzarella S., Zanca R. (1985). Il libro delle torri. Le torri costiere di Sicilia nei secoli XVI-XX. Sellerio Ed. Palermo. pp. 13-124, 254-260.

Pelletier M. (1994) "Der Portolan von Angelino Dulcert, 1339" in Cartographica Helvetica : Fachzeitschrift für Kartengeschichte. ETH. Zürich.

Russo F. (1994) La difesa costiera del Regno di Sicilia dal XVI al XIX secolo. S. M. dell'Esercito. Roma Trovato R. (1993). Marine del Regno di Sicilia-Tiburzio Spannocchi. Ordine Arch. di Catania. Catania. 